\title{
Pharmaceutico-analytical study of Praval Bhasma (Coral calax) with two different herbs
}

\author{
Research Article
}

\section{Arati P Dubewar1 ${ }^{*}$, Uday S Londhe ${ }^{2}$, Medha S Kulkarni ${ }^{3}$, Pradnya Kakodkar ${ }^{4}$, Anupama R Dashetwar5, Ashwin Shete 6}

1. Professor HOD \& PhD Guide, 6. PhD Scholar \& Assistant Professor, Department of Rasashastra evam Bhaishajyakalpana, Dr D Y PatilVidyapeeth deemed to be University. Dr. D.Y.Patil College of Ayurved \& Research Center, Pimpri, Pune.

2. Assistant Professor, Department of Oral \& Maxillofacial Surgery, Dr D Y Patil Dental College, Pimpri, Pune.

3. Professor, Department of Swasthvritta, All India Institute of Ayurveda New Delhi.

4. Deputy Director, Dr D Y Patil Vidyapeeth deemed to be University. Pune.

5. Associate Professor, Medicinal Chemstry Depatment, R D College of Pharmacy, Bhor, Dist Pune.

\begin{abstract}
Introduction: In the present study, Praval is used as a raw material to form Praval Bhasma. Praval (Coral) is the calcareous skeleton of the minute marine organism called Anthezoa polypus and belongs to phylum coelenterate. It is a natural source of rich calcium widely used in Deepan, Pachan, Amlapitta Raktapitta, Yakshma, Kasa, Netra Roga and Hridaya Roga (1)and Calcium deficiency diseases etc. it is administered in the form of Bhasma and Pishti. Method: Shodhan of Praval is done in Sarjika kshara. The Pravala bhasma is prepared by two different method by triturating it with Kumari Swaras and Guduchi Kashay and incineration in Muffle furnace. physico-chemical tests like Total Ash, Acid Insoluble Ash, Loss on Drying, and Qualitative analysis of praval bhasma by NPST (Namburi Phased Spot Test) are done. Result \& conclusion: Praval bhasma prepared by two different medicines shows potency, efficacy for further clinical use.
\end{abstract}

Key Words: Shodhana, Marana, Kumari, Guduchi, Muffle furnace. Anthezoa polyps.

\section{Introduction}

Praval bhasma is used in ayurveda for the treatment of Osteoporosis, Praval is the calcareous skeleton of minute marine organisms called Anthozoa polypus and belongs to phylum coelenterate. The Skeleton is in the form of minute irregular deposits, called spicules which contain mainly calcium carbonate. In human bone, amorphous calcium carbonate (ACC) is formed as a Precursor of the crystalline carbonated apatite/hydroyapatite (HA).The Calcium carbonate (CC)Skeleton of marine corals has been reported to be biodegradable and osteoconductive. The transformation of the calcium carbonate surface (Degeneration and new crystal formation) is perquisite for osteoblastic apposition and differentiation of osteo progenitor cells into osteogenic cells which ultimate lead to bone formation .For bhasma preparation two different dravya are used 1.Kumari(Aloe Vera Tourn. Ex Linn) Swaras, 2.Guduchi(Tinospora cordifolia (Willd.) Hook. f. and Thoms) Decoction for trituration.

* Corresponding Author:

\section{Arati P Dubewar}

Professor \& HOD, Department of Rasashastra evam Bhaishajyakalpana, (Dr D Y PatilVidyapeeth deemed to be University). Dr. D.Y.Patil College of Ayurved \& Research Center, Pimpri, Pune-18. India. Email Id: aratidubewar@gmail.com
- Kumari Swaras which contain mainly Calcium oxalate Lf,Calcium Lf 190-4600,Carbonate Lf Carbohydrates,Lf $89.6 \%$. Several mechanism are known which potentiate the immune system ${ }^{2}$.

- Guduchi is immune modulator has highest immune stimulatory activity.

To ensure the quality and to establish the standard parameters for study, the physicochemical characterization of Praval Bhasma was performed. Qualitative analysis of praval bhasma by NPST(Namburi Phased Spot Test) was done.

No any previous work done on this research experiment.

Experimental research study design was used in this research.

\section{Need of Study}

Puranam cha punarnavam-The use of ancient medicines for newer invention is present days need. For this purpose we prepared and standardized Praval Bhasma by two different methods

\section{Aim \& Objectives}

- Pharmaceutical study of Shodhana of Praval with Sajjikshar jala.

- Pharamceutical study of marana of Pravala with Guduchi and Kumari. 
- Analytical study of Praval bhasma with ayurvedic and modern parameters.

- Analytical study with reference to NPST analytical test of both the samples.

\section{Materials and Methods \\ Raw materials-}

1. Pravala- was procured from a local market of Mumbai, India (Figure1).

2. Sarjikakshara- which is also called Sajjikhar (sodium bicarbonate) was purchased from Local market of Pune .

3. Kumari Swaras-Collect from garden of Dr D Y Patil College of Ayurved \& Research Center ,Pimpri,Pune-18.

4. Guduchi Stem-was purchased from local market of Pune.

\section{Prepapration of Praval Bhsama \\ Shodhana(Cleaning)(2)}

Praval was purified according to sodhana process described in Rasa Tarangini. During Sodhana process Pravala was kept in a musaline cloth and pottali was prepared. This pottali was hung in pot, containing Sarjika Kshar + Jala mixture with the help of bamboo rod and heat was given continuously for 1 prahar( 3 hours). Later the pottali was removed from the pot. After removing Praval was washed, dried of shudha Praval.(Fig 1)

Figure 1: Praval Shodhana
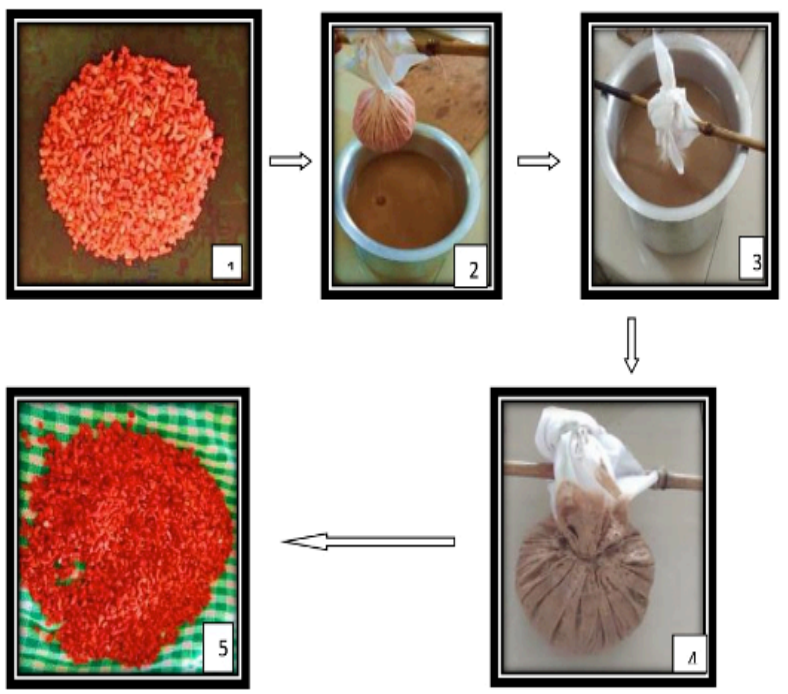

Figurel Praval Shodhana: 1)Raw Praval,2)Sajjikshar+Jala-Praval Pottali,3)Praval Pottali Kept in Sajjikshar-Jala mixture,4)Praval Pottali after heating 3hrs in Sajjikshar-Jala mixture,5) Shudha Praval

\section{Maranam (Incineration)}

After sodhana process the shudha Praval was subjected to marana

(incineration) process. Shudha Praval was devided into two parts then Bhavana of Kumari Swaras was given to $1 / 2$ quantity of shudha praval powder to make a weak (semi-solid paste) and the circular chakrikas of $2-3 \mathrm{~cm}$ in diameter were prepared. (Fig 2)
Fig 2: Praval Bhasma by Kumari Swarasa

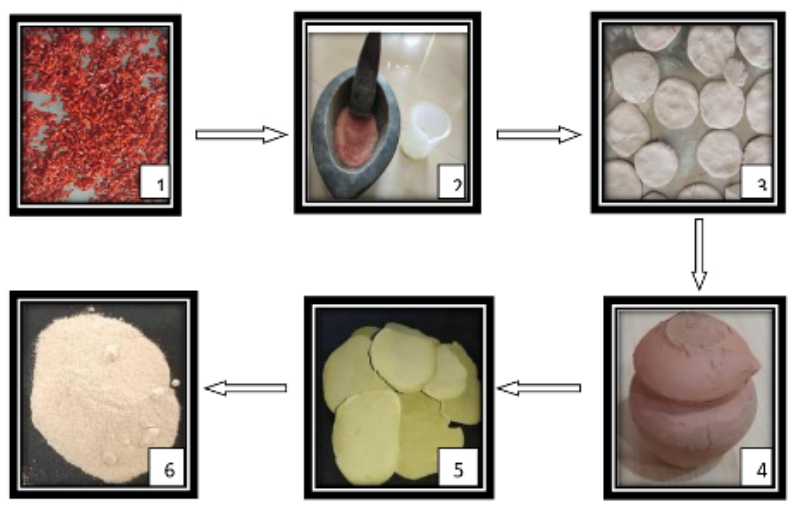

Figure 2 Praval bhasma by kumari swaras-1)Shudha Praval,2)shudha Praval Kumari Swaras,3)Chakrika of Praval,4)Earthen Vessel containg Praval Chakrika,5)Praval chakrika after puta,6)Praval Bhasma.

For remaining Shudha Praval powder bhavana of guduchi decoction was given to make a weak and the circular chakrika were prepared. The chakrikas (round and flat pellets) were dried in shade and kept in an earthen vessels(3). (Fig 3)

The joint of both earthen vessels was sealed with the help of mat-kapad [ribbon of muslin cotton cloth smeared with multani mitti( fuller's earth)] and dried . Finally the sealed vessel was subjected to Muffle furnace. The temperature adjusted to the maximum of $800^{\circ} \mathrm{C}$ during the process. Total time taken in ignition and swangshita was $10 \mathrm{hrs}$ and $30 \mathrm{~min}$. Total process is called one puta. The Earthen vessel was removed from muffle furnace Chakrikas were again triturated with Kumari swaras. Again the flat thin Chakrikas (pellets) were prepared, dried in shade and kept in earthen vessel; finally subjected to muffle furnace. The process was repeated thrice. This process was used for preparation of praval bhasma. Same procedure was repeated for preparation of praval bhasma by guduchi decoction.

\section{Fig 3: Praval bhasma prepared with Guduchi kwath(decoction)}
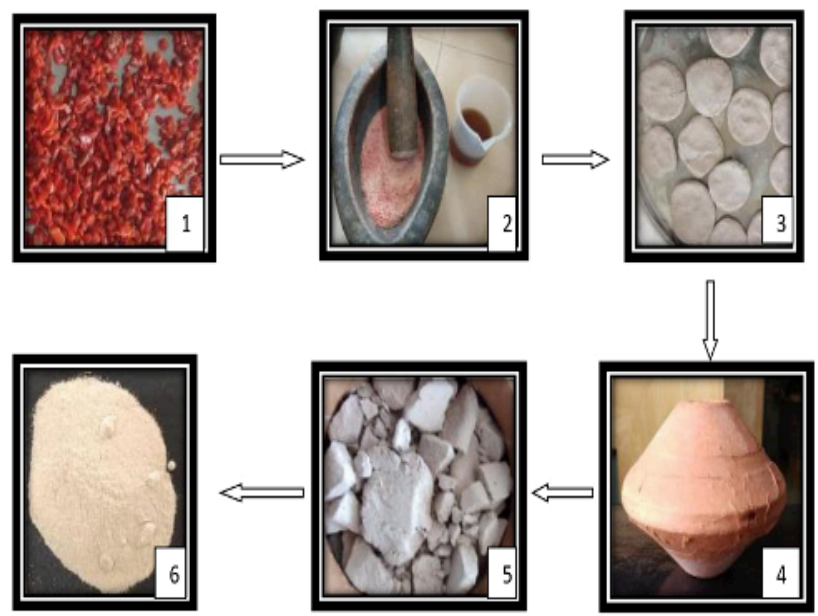

Figure 3Praval bhasma prepared from Guduchi decoction-1)Shudha Praval,2)shudha Praval+Guduchi Decoction,3)Chakrika of Praval,4)Earthen Vessel containg Praval Chakrika,5)Praval chakrika after puta,6)Praval Bhasma. 


\section{Physiochemical property analysis}

Physiochemical properties were analyzed using API (formulation) at analytical lab of Dr D.Y.Patil College of Ayurved\& Research Center, Pimpri, Pune-18.

\section{Organoleptic characters of Praval bhasam}

The final bhasma was analyzed for quality control as described in Ayurvedic text .

Eg: Rekhapurnatvam

\section{Varitaramtav.}

\section{Observations}

After Shodhan(Purification) Shudha Praval was divided in two groups for preparation of Praval Bhasma by two different methods. Physicochemical tests are done and values obtained.

Raw praval of $250 \mathrm{gm}$ was subjected for shodhana. After shodhana10gm loss seen. (Table1)

Table 1-Pharmaceutical Preparation of Praval Shodhan

\begin{tabular}{|c|c|c|}
\hline S.No & $\begin{array}{c}\text { Quantity of Praval for Shodhan } \\
\text { (Purification) }\end{array}$ & Obtained \\
\hline 1 & Before & $250 \mathrm{gm}$ \\
\hline 2 & After & $240 \mathrm{gm}$ \\
\hline 3 & Loss & $10 \mathrm{gm}$ \\
\hline
\end{tabular}

In Pharmaceutical preparation of praval bhasma by kumari swaras, in three batches loss in weight seen.(Table 2)

Table 2: Pharmaceutical preparation of praval bhasma by kumari swaras.

\begin{tabular}{|c|c|c|c|c|}
\hline $\mathbf{S r}$ & \multicolumn{2}{|c|}{ Procedure } & $\begin{array}{l}\text { Quantity } \\
\text { Taken }\end{array}$ & $\begin{array}{l}\text { Quantity } \\
\text { Obtained }\end{array}$ \\
\hline & \multicolumn{2}{|c|}{$\begin{array}{l}\text { Initial weight of powdered } \\
\text { Praval }\end{array}$} & $120 \mathrm{gm}$ & \\
\hline \multirow[t]{3}{*}{1} & \multirow{3}{*}{$\begin{array}{l}\text { Marana } 1^{\text {st }} \\
\text { Puta }\end{array}$} & Before & $120 \mathrm{gm}$ & \\
\hline & & $\begin{array}{l}\text { After } \\
\text { Bhavana }\end{array}$ & $120 \mathrm{gm}$ & $130 \mathrm{gm}$ \\
\hline & & After Puta & $130 \mathrm{gm}$ & $105 \mathrm{gm}$ \\
\hline \multirow[t]{3}{*}{2} & \multirow{3}{*}{$\begin{array}{l}\text { Marana 2 } 2^{\text {nd }} \\
\text { Puta }\end{array}$} & Before & $105 \mathrm{gm}$ & \\
\hline & & $\begin{array}{l}\text { After } \\
\text { Bhavana }\end{array}$ & $105 \mathrm{gm}$ & $125 \mathrm{gm}$ \\
\hline & & After Puta & $125 \mathrm{gm}$ & $100 \mathrm{gm}$ \\
\hline \multirow[t]{3}{*}{3} & \multirow{3}{*}{$\begin{array}{l}\text { Marana } 3^{\text {rd }} \\
\text { Puta }\end{array}$} & Before & $100 \mathrm{gm}$ & \\
\hline & & $\begin{array}{l}\text { After } \\
\text { Bhavana }\end{array}$ & $100 \mathrm{gm}$ & $124 \mathrm{gm}$ \\
\hline & & After Puta & $124 \mathrm{gm}$ & $96.155 \mathrm{gm}$ \\
\hline
\end{tabular}

In bhasma process with guduchi swaras also shows loss in weight. (Table 3 )
Table 3: Pharmaceutical preparation of praval bhasma by guduchi decoction

\begin{tabular}{|c|c|c|c|c|}
\hline $\begin{array}{l}\text { Sr } \\
\text { No. }\end{array}$ & \multicolumn{2}{|c|}{ Procedure } & $\begin{array}{l}\text { Quantity } \\
\text { Taken }\end{array}$ & $\begin{array}{l}\text { Quantity } \\
\text { Obtained }\end{array}$ \\
\hline & \multicolumn{2}{|c|}{$\begin{array}{l}\text { Initial weight of powdered } \\
\text { Praval }\end{array}$} & $120 \mathrm{gm}$ & \\
\hline \multirow[t]{3}{*}{1} & \multirow[t]{3}{*}{ Marana 1 st Puta } & Before & $120 \mathrm{gm}$ & $120 \mathrm{gm}$ \\
\hline & & $\begin{array}{l}\text { After } \\
\text { Bhavana }\end{array}$ & $120 \mathrm{gm}$ & $135 \mathrm{gm}$ \\
\hline & & After Puta & $135 \mathrm{gm}$ & $114 \mathrm{gm}$ \\
\hline \multirow[t]{3}{*}{2} & \multirow[t]{3}{*}{ Marana $2^{\text {nd }}$ Puta } & Before & $114 \mathrm{gm}$ & \\
\hline & & $\begin{array}{l}\text { After } \\
\text { Bhavana }\end{array}$ & $114 \mathrm{gm}$ & $138 \mathrm{gm}$ \\
\hline & & After Puta & $138 \mathrm{gm}$ & $110 \mathrm{gm}$ \\
\hline \multirow[t]{3}{*}{3} & \multirow[t]{3}{*}{ Marana 3rd Puta } & Before & $110 \mathrm{gm}$ & \\
\hline & & $\begin{array}{l}\text { After } \\
\text { Bhavana }\end{array}$ & $110 \mathrm{gm}$ & $136 \mathrm{gm}$ \\
\hline & & After Puta & $136 \mathrm{gm}$ & $100 \mathrm{gm}$ \\
\hline
\end{tabular}

Organoleptic characters of both bhasma are same except in color. Kumari swaras bhasma is white whereas other is creamish white.(Table 4)

Table 4: Organoleptic Character and Ayurvedic Pariksha for Praval Bhasma

Sr No Parameter Praval bhasma Praval bhasma prepared from prepared from Kumari Guduchi decoction

\begin{tabular}{ll|l|}
1 Color & White & Creamish white \\
2 Odour & Odourless & Odourless \\
\hline 3 Taste & Chalklike & Chalklike \\
\hline 4 Touch & Smooth & Smooth \\
\hline 5 Appearance & $\begin{array}{l}\text { Amorphous } \\
\text { powder }\end{array}$ & $\begin{array}{l}\text { Amorphous } \\
\text { powder }\end{array}$ \\
\hline 6 Rekhapurnatva & Present & Present \\
\hline 7 Varitaratva & Present & Present
\end{tabular}

Physicochemical Analysis of both bhasma in terms of The Total Ash Value,Acid Insoluble Ash, Water soluble Ash,Loss on drying at $110^{\circ} \mathrm{C}$ shows slight difference( 4 \&5). (Table 5)

Table 5: Physico-Chemical Properties of PravalBhasma

\begin{tabular}{|c|l|c|c|}
\hline Sr No. & Parameter & $\begin{array}{l}\text { PravalBhasm } \\
\text { a by Kumari } \\
\text { Swaras }\end{array}$ & $\begin{array}{l}\text { PravalBhasma } \\
\text { by Guduchi } \\
\text { Decoction }\end{array}$ \\
\hline 1 & Total Ash & $92.85 \% \mathrm{w} / \mathrm{w}$ & $88.5 \% \mathrm{w} / \mathrm{w}$ \\
\hline 2 & Acid Insoluble Ash & $0.144 \% \mathrm{w} / \mathrm{w}$ & $0.29 \% \mathrm{w} / \mathrm{w}$ \\
\hline 3 & Water Soluble Ash & $0.5 \% \mathrm{w} / \mathrm{w}$ & $0.46 \% \mathrm{w} / \mathrm{w}$ \\
\hline 4 & $\begin{array}{l}\text { Loss on Drying at } \\
110^{\circ} \mathrm{C}\end{array}$ & $0.49 \% \mathrm{w} / \mathrm{w}$ & $0.42 \% \mathrm{w} / \mathrm{w}$ \\
\hline 5 & $\begin{array}{l}\text { Qualitative analysis } \\
\text { Calcium }\end{array}$ & Present & Present \\
\hline 6 & $\begin{array}{l}\text { Qualitative analysis } \\
\text { Calcium }\end{array}$ & Present & Present \\
\hline
\end{tabular}


Observation during NPST of Praval bhasma by both methods shows bright red spot of different diameter.(6)(Table 6), (Fig 4)

Fig 4: NPST of Praval bhasma by both methods shows bright red spot of different diameter
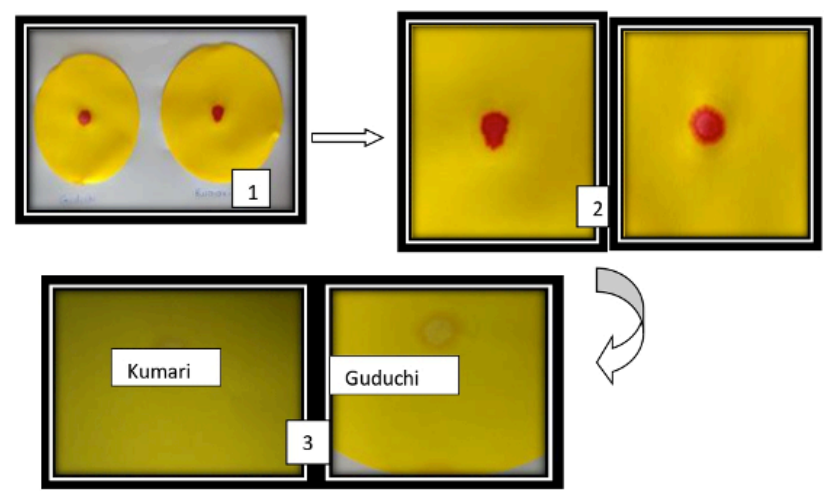

Table 6: Observation during NPST of Praval bhasma

\begin{tabular}{|c|c|c|c|}
\hline \multicolumn{2}{|c|}{ Criteria } & $\begin{array}{l}\text { Praval } \\
\text { Bhasma } \\
\text { prepared } \\
\text { from Kumari } \\
\text { Juice } \\
\text { (Swarasa) }\end{array}$ & $\begin{array}{l}\text { Praval } \\
\text { Bhasma } \\
\text { prepared } \\
\text { from } \\
\text { Guduchi } \\
\text { decoction }\end{array}$ \\
\hline \multirow{3}{*}{$\begin{array}{l}\text { Changes on } \\
\text { Heating in } \\
\text { micro test tube } \\
\text { to the bottom of } \\
\text { test tube } \\
\text { becomes red } \\
\text { hot }\end{array}$} & $\begin{array}{l}\text { Liberation of } \\
\text { fumes }\end{array}$ & Nil & $\begin{array}{l}\text { Small } \\
\text { quantity }\end{array}$ \\
\hline & Charring & Nil & Nil \\
\hline & Odour & Nil & Nil \\
\hline \multirow[t]{5}{*}{$\begin{array}{l}\text { Changes On } \\
\text { Wetting }\end{array}$} & $\begin{array}{l}\text { Exothermic } \\
\text { reaction }\end{array}$ & Not found & Not found \\
\hline & $\begin{array}{l}\text { Endothermic } \\
\text { reaction }\end{array}$ & Not found & Not found \\
\hline & $\begin{array}{l}\text { Colour of } \\
\text { the solution }\end{array}$ & Colourless & Colourless \\
\hline & Absorption & Fast & Fast \\
\hline & Settling time & Rapidly & Rapidly \\
\hline $\begin{array}{l}\text { Fading away } \\
\text { time }\end{array}$ & Rapid & Rapid & \\
\hline $\begin{array}{l}\text { Color Pattern } \\
\text { Initially }\end{array}$ & $\begin{array}{l}\text { Formation of } \\
\text { dark pink } \\
\text { spot }\end{array}$ & $\begin{array}{l}\text { Formation of } \\
\text { dark pink } \\
\text { spot }\end{array}$ & \\
\hline $\begin{array}{l}\text { Color Pattern of } \\
1 \text { st phase (After } \\
5 \text { minutes) }\end{array}$ & $\begin{array}{l}\text { Formation of } \\
\text { pink spot } \\
\text { wet } \\
\text { periphery. }\end{array}$ & $\begin{array}{l}\text { Formation of } \\
\text { pink spot wet } \\
\text { periphery. }\end{array}$ & \\
\hline $\begin{array}{l}\text { Color Pattern of } \\
2^{\text {nd }} \text { phase (After } \\
20 \text { minutes) }\end{array}$ & $\begin{array}{l}\text { Fading away } \\
\text {-Light pink } \\
\text { spot }\end{array}$ & $\begin{array}{l}\text { Fading away } \\
\text {-Light pink } \\
\text { spot }\end{array}$ & \\
\hline $\begin{array}{l}\text { Color Pattern of } \\
3^{\text {rd }} \text { phase } \\
\text { (After } 6 \text { hours) }\end{array}$ & $\begin{array}{l}\text { Central } \\
\text { circle fade } \\
\text { away rapidly }\end{array}$ & $\begin{array}{l}\text { Central circle } \\
\text { fade away } \\
\text { rapidly }\end{array}$ & \\
\hline
\end{tabular}

\section{Qualitative Analysis}

NPST test is a chemical test done as per NPST

Book $^{6}$. Result obtained in fig 4 and Table 6 , to detect the Calcium and Carbonate content which is important for growth of stem cells in bone formation.

\section{Discussion}

Praval (Coral )is obtained from sea water naturally. In raw form it contains many impurities.to use in formulation there impurities has to be removed .In Ayurveda Praval is used as Bhasma or Pisti form. Before preparation of bhasma it is necessary to purify the raw Praval, shodhan is the process advised in texts for purification. Shodhana is done by various methods like trituration(Bhavana), Frying (Bharjana), swedana (Steaming)etc. Regarding Praval, steaming (Swedana) of different drugs used in this context.

To remove the impurities, use of Kshariya or alkaline Sajjiksharjal is recommended in the texts. After purification Praval looses its shine it becomes dull, fragile and soft enhancing the absorption.

For bhasmikarana, different drugs are used as per their properties. Shuddha pravala is triturated with various drugs. Then made into flat cakes, to be dried in sunlight and subjected to appropriate fire. Aloe vera triturated chakrika (Flat cakes) became more shiny and strong than guduchi chakrika. Aloe vera (Kumari) is sheet, balya, and rasayan (immuno-modulator) Aloe vera also has anti-inflammatory activity ,ulcer healing property and immune modulatory activity.(7) Due to these qualities it may help in growth of stem cells. It also contains Calcium oxalate Lf, Calcium Lf 190-4600,Carbonate Lf, Carbohydrates Lf $89.6 \%$ Calcium. These might increase the Calcification action of drug .Synonym of Guduchi is Amruta which donates immortality .Guduchi is also balya and rasayan has highest immune stimulatory activity alcolides Magnoflorin -increases bioavabality, Tembetarine, Deterpinoides- Borapetol, Tinosporide, Cordifoloside A-C,Courdioside, Miscellaneous-Cordiofolide A and B. Minor elements namely $\mathrm{Cl}, \mathrm{K}, \mathrm{Ca}, \mathrm{Ti}, \mathrm{Cr}, \mathrm{Mn}, \mathrm{Fe}, \mathrm{Co}$, $\mathrm{Ni}, \mathrm{Cu}, \mathrm{Zn}, \mathrm{Br}$, and $\mathrm{Sr}$ in Tinospora cordifolia. The very high concentrations of $\mathrm{Cl}, \mathrm{K}$, and $\mathrm{Ca}$ in all the leaf samples, appreciable levels of $\mathrm{Mn}$ and high $\mathrm{Zn}$ content in T. cordifolia.(8) So that Guduchi is being used in this experiment.

By Trituration with Guduchi an organo-mineral complex is formed which enhance bio assimilative effect of Praval. By process of mardana looses molecular cohesiveness and Praval become fragile and soft ultimately improving absorption property.

\section{Conclusion}

- Bhasma fulfilled the NSPT Standards and both compared with each other.

- Pharmaceutical study of Shodhana of Praval with Sajjikshar jala done and it shows loss of shine and change in fragility.

- Pharamceutical study of marana of Pravala with Guduchi and Kumari.It shows almost same ayurvedic properties like smell, color etc.

- Analytical study of Praval bhasma with ayurvedic and modern parameters. All ayurvedic parameters fulfilled. Modern parameters shows difference in their ash value and solubility. 
- Analytical study with reference to NPST of both the samples done and shows dark red spot on sheet.

Further scope of the study is, osteogenic ayurvedic drugs can be used in all type of bone disorders like fractures, osteo-malacia, osteoporosis etc.

\section{References}

1. Sadananda Sharma, Edited by Kasinath Shastri, Rasa Tarangini., 8th edition, Varanasi, Motilal Banarasi Das, 2014,pg 625-632.

2. Mukund Sabnis,Chemistry and Pharmacology of Ayurvedic Medicinal Plants, 1 st Edition, Varanasi ,Chaukhamba Amarbharati Prakashan, 2006.,pg100-107,338-344.

3. Ravindra Angadi,Text Book of Rasashastra-ItroChemistry and Ayurvedic Pharmaceutics, Reprint Ed-2018, Varanasi ,Chaukhamba Surbharati Prakashan Varanasi, Chaukhamba Publishing House;2018,pg.438-446.

4. Pharmacopoeial Standards of Ayurvedic formulations, Yugantar Prakashan,Central Concil for
Research in Ayurveda and Siddha,51,511,522. New

Delhi: CCRAS publication, 2010, pg52-54.

5. Lohar D R ,Protocol for Testing of Ayurvedic ,Siddha and Unani medicines, 1 st $^{\text {st }}$ edition, Ghaziabad, Govt of India,Dept of Ayush,Ministry of Health \& Family welfare;Pharmacopoeial Laboratory for Indian Medicines, Ghaziabad, Jan 2008,pg 49-50.

6. Namburi Hanumanth Rao, Manual of Namburi phased Spot test, Vijayawada, Namburi Inventions and Publication, 1997, pg 29.

7. Sharrif Moghaddasi M, Sandeep Kumar Verma, Aloe vera their chemicals composition and applications: A review, International Journal of Biological \& Medical Research; Int J Biol Med Res. 2011; 2(1): 466-471.

8. Devprakash, K.K.Srinivasan, T.Subburaju, Suhas gurav \& Sachin singh "Tinospora Cordifolia:- $A$ Review On Its Ethnobotany, Phytochemical \& Pharmacological Profile." Asian Journal of Biochemical and Pharmaceutical Research, 2011,Issue 4 (Vol. 1),306-317. 